\title{
Drivers of change in biodiversity and ecosystem services in the Cantareira System Protected Area: A prospective analysis of the implementation of public policies
}

\author{
Viviane Dib $^{1,2, *}$ (D, Marco Aurélio Nalon ${ }^{3}$, Nino Tavares Amazonas ${ }^{4}$, Cristina Yuri Vidal,
}

Iván A. Ortiz-Rodríguez ${ }^{6}$, Jan Daněk ${ }^{7,8} \mathbb{D}^{\circ}$, Maíra Formis de Oliveira ${ }^{9}$, Paola Alberti $^{10}$, Rafaela Aparecida da

Silva $^{11}$, Raíza Salomão Precinoto ${ }^{1}$ (D) \& Taciana Figueiredo Gomes ${ }^{12}$ (D).

${ }^{1}$ Universidade Federal do Rio de Janeiro, Instituto de Biologia, Departamento de Ecologia, Av. Carlos Chagas Filho, 373, CEP: 21941-971, Cidade Universitária, Ilha do Fundão, Rio de Janeiro, RJ, Brasil.

${ }^{2}$ Instituto Internacional para Sustentabilidade, Estrada Dona Castorina, 124, CEP 22460-320, Horto, Rio de Janeiro, RJ, Brasil.

${ }^{3}$ Instituto Florestal, Secretaria de Infraestrutura e Meio ambiente do Estado de São Paulo, Rua do Horto, 931, CEP 02377000, São Paulo, SP, Brasil.

${ }^{4}$ Universidade de São Paulo, Escola Superior de Agricultura “Luiz de Queiroz”, Departamento de Ciências Biológicas, Laboratório de Silvicultura Tropical, Av. Pádua Dias, 11, CEP 13418-900, Piracicaba, SP, Brasil.

${ }^{5}$ Universidade de São Paulo, Escola Superior de Agricultura "Luiz de Queiroz”, Departamento. de Ciências Biológicas, Laboratório de Ecologia e Restauração Florestal, Av. Padua Dias, 11, CEP 13418-900,

Piracicaba, SP, Brasil.

${ }^{6}$ Classe di Scienze, Scuola Normale Superiore, Piazza dei Cavalieri 7, 56126, Pisa, Italy.

${ }^{7}$ Global Change Research Institute of the Czech Academy of Sciences, Brno, Bélidla 986/4a, 60300 Brno, Czech Republic.

${ }^{8}$ Charles University in Prague, Faculty of Humanities, U Kř́že 8, 15800 Praha 5, Czech Republic.

${ }^{9}$ Secretaria de Agricultura e Abastecimento do Estado de São Paulo, Praça Ramos de Azevedo, 254, CEP 01037-912, Centro, São Paulo, SP, Brasil.

${ }^{10}$ Instituto de Biodiversidad Neotropical, CONICET, Universidad Nacional de Tucumán, Facultad de Ciencias Naturales, Ciudad Universitaria, 4107, Horco Molle, Tucumán, Argentina.

${ }^{11}$ Universidade Federal de Goiás, Departamento de Ecologia, Avenida Esperança s/n, CEP 74001-970, Samambaia, Goiânia, GO, Brasil.

${ }^{12}$ Universidade de São Paulo, Centro de Energia Nuclear na Agricultura, Laboratório de Ecologia Isotópica, Avenida Centenário, 303, CEP 13416-000, São Dimas, Piracicaba, SP, Brasil.

*Corresponding author: Viviane Dib, e-mail: dibviviane@gmail.com

DIB, V., NALON, M.A., AMAZONAS, N.T., VIDAL, C.Y., ORTIZ-RODRÍGUEZ, I.A., DANĚK, J., OLIVEIRA, M.F., ALBERTI, P., SILVA, R.A., GOMES, T.F., PRECINOTO, R.S. Drivers of change in biodiversity and ecosystem services in the Cantareira System Protected Area: A prospective analysis of the implementation of public policies. Biota Neotropica 20(suppl1): e20190915. https://doi.org/10.1590/1676-0611-BN-2019-0915

Abstract: The lack of implementation of well-designed public policies aimed at the conservation of natural ecosystems has resulted, at a global level, in the decline of ecosystem functioning and, consequently, of the contributions they make to people. The poor enforcement of important environmental legislation in Brazil - for instance, the "Atlantic Forest Law" (Law n.11.428/2006) and the "Forest Code" (Law n.12.651/2012) - could compromise the overall maintenance of ecosystems and the services they provide. To explore the implications of different levels of federal laws' enforcement within the Cantareira System Protected Area (PA) - a PA in southeastern Brazil that provides fresh water for $47 \%$ of the Sao Paulo Metropolitan Area -, we developed a conceptual framework to identify indirect and direct drives of biodiversity and ecosystem changes. We also projected four land-use scenarios to 2050 to test the effects of deforestation control and forest restoration practices on biodiversity and ecosystem services maintenance: the "business-as-usual" scenario (BAU), which assumes that all trends in land-use cover changes observed in the past will continue in the future, and three alternative exploratory scenarios considering the Atlantic Forest Law implementation, the partial implementation of the Forest Code and the full implementation of the Forest Code. Using the land-use maps generated for each scenario, we assessed the impacts of land-use changes on biodiversity conservation and soil retention. Our results revealed all alternative scenarios could increase biodiversity conservation (by $7 \% ; 12 \%$; and $12 \%$, respectively), reduce soil 
Dib, V. et al.

loss (by $24.70 \% ; 34.70 \%$; and $38.12 \%$, respectively) and sediment exportation to water (by $27.47 \% ; 55.06 \%$; and $59.28 \%$, respectively), when compared to the BAU scenario. Our findings highlight the importance of restoring and conserving native vegetation for the maintenance and improvement of biodiversity conservation and for the provision of ecosystem services.

Keywords: Biodiversity, Ecosystem services, Scenarios, Modeling, Cantareira System Protected Area, GLOBIO, InVEST.

\section{Agentes de mudança na biodiversidade e serviços ecossistêmicos na APA Sistema Cantareira: Uma análise prospectiva da implementação de políticas públicas}

Resumo: A falta de implementação de políticas públicas voltadas para a conservação ambiental, tem resultado, em nível global, em impactos sobre a biodiversidade e o funcionamento dos ecossistemas e, consequentemente, na contribuição da natureza para as pessoas. A aplicação inadequada de importantes de leis ambientais no Brasil, como por exemplo, a "Lei da Mata Atlântica" (Lei no 11.428 / 2006) e o "Código Florestal" (Lei n” 12.651 / 2012), podem comprometer a manutenção dos ecossistemas e dos serviços que eles fornecem. Neste estudo, nós desenvolvemos um mapa conceitual que busca identificar causas diretas e indiretas de mudanças - agentes de mudança - na biodiversidade e na provisão de serviços ecossistêmicos relacionados ao solo e à água, na Área de Proteção Ambiental (APA) Sistema Cantareira. A APA Sistema Cantareira, localizada no sudeste do Brasil, fornece água potável para 47\% da Região Metropolitana de São Paulo. Além da abordagem conceitual, nós projetamos quatro cenários de mudança no uso da terra para o ano de 2050, a fim de analisar o impacto de diferentes níveis de aplicação de leis federais: o cenário "business-as-usual" (BAU), que pressupõe que as tendências na mudança de uso da terra observadas no passado continuarão no futuro, e três cenários alternativos, considerando a implementação da Lei da Mata Atlântica, a implementação parcial do Código Florestal e a implementação completa do Código Florestal. A partir dos mapas de uso da terra gerados, avaliamos os impactos de cada cenário na conservação da biodiversidade, na retenção de solos e na exportação de sedimentos para os corpos d'água. Nossos resultados mostraram que os três cenários alternativos podem aumentar a conservação da biodiversidade (em 7\%; 12\%; e 12\%, respectivamente), reduzir a perda de solo (em 24,70\%; 34,70\%; e $38,12 \%$, respectivamente) e reduzir a exportação de sedimentos para a água (em 27,47 \%; 55,06\%; e 59,28\%, respectivamente), quando comparados ao cenário BAU. Este estudo destaca a importância da restauração e conservação da vegetação nativa para a manutenção da biodiversidade e melhoria na provisão de serviços ecossistêmicos relacionados ao solo e à água, em uma região estratégica para o abastecimento de água no Brasil. Palavras-chave: Biodiversidade, Serviços ecossistêmicos, Modelagem, Área de Proteção Ambiental Sistema Cantareira, GLOBIO, InVEST.

\section{Introduction}

Human well-being depends directly and indirectly on nature, and the complexity of these interactions is very difficult to map or measure. Despite these difficulties, there is abundant evidence worldwide that overall improvement in human well-being and economic development have resulted in negative impacts on biodiversity and ecosystem services (hereafter BES) (MEA 2005, IPBES 2018, 2019). According to these estimates, human activities have modified about half of the land and diverted half of the freshwater around the planet (MEA 2005, McGill 2015), triggering severe negative consequences for terrestrial and aquatic biodiversity and for their related ecosystem services, and affecting the long-term provision, regulation and maintenance of water, food, climate, soil and nutrient cycling. To reverse the consequences of ecosystem degradation for BES, the Millennium Ecosystem Assessment (MEA) was the first to compile, back in 2005, the scientific basis of the conditions and trends in the world's ecosystems and the services they provide (such as clean water, food, forest products, flood control, and natural resources); as well as the options to restore, conserve or enhance their sustainable use. Reinforced by the information of other international assessments, such as the Intergovernmental Panel on Climate Change (IPCC), it was clear that the science-policy interface had to grow stronger to foster sustainable development. With that purpose, the Intergovernmental Platform on Biodiversity and Ecosystem Services (IPBES 2018) was established in 2012, aiming to assess and update current knowledge, stimulate new advances and support policy formulation and implementation (Díaz et al. 2015). Modeling the influence of human-driven changes on BES is of vital importance in the global context of the environmental crisis described above. Model-based analysis can inform decision-making, by enabling the understanding of the implications of different scenarios for biodiversity conservation and ecosystem functioning (Pereira 2010).

Human activity is having a significant impact on water resources and in some places it is actually constraining freshwater availability (Ceola et al. 2015). Freshwater bodies (e.g. rivers, lakes and groundwater) are subject to a wide variety of habitat transformation and degradation, including hydrological manipulations (dams and reservoirs), pollution by sewage waste, contamination by toxic substances and introduction of exotic species, amongst others (Hoekstra \& Wiedmann 2014, Martin- 
Ortega et al. 2015). Water provides key ecosystem services of all sorts - support, regulation, provision or cultural services - with complex inter-linkages with ecosystems functioning: it maintains terrestrial and aquatic species and habitats, regulates micro and local climate, provides drinking water for human consumption, but also for fish, agricultural and industrial production, affecting different components of human well-being (Grizzetti et al. 2016, IUFRO 2018). For these reasons, the conservation of freshwater ecosystems and their biodiversity has been receiving much attention in recent years and is now considered a priority issue at the global level (MEA 2005, Hoestra \& Wiedmann 2014, Schiermeier 2014, IUFRO 2018, IPBES 2018). It is estimated that, at the global level, we consume from 22 to $150 \%$ of the annual freshwater supply (1,000 to 1,700 billion $\mathrm{m}^{3} /$ year) (Hoekstra \& Wiedmann 2014), and official reports for the Americas revealed a declining water supply per capita and unsustainable use of surface and groundwater (IPBES 2018). For instance, Brazil has abundant aboveground water (Pires et al. 2019) and yet water shortage events are getting quite common, especially within regions with a long history of land use conversion, reduced vegetation cover and increased human population (Schiermeier 2014, IPBES 2018). That is precisely the situation for the state of São Paulo, southeastern Brazil, which has experienced severe water scarcity episodes during the past few years (Loyola \& Bini 2015).

The destruction and degradation of natural ecosystems is the major cause of biodiversity loss on the planet (Haddad et al. 2015, McGill 2015, Newbold et al. 2015) and it is particularly threatening for the tropical region, which supports over half of the world's terrestrial biodiversity (Malhi et al. 2014). Several studies showed that ecosystems functions and services depend upon local biodiversity (Isbell et al. 2011, Cardinale et al. 2012, Tilman et al. 2014), highlighting the direct and indirect benefits of biodiversity conservation to ecosystem productivity, stability, invasibility and nutrient dynamics (Tilman et al. 2014, Isbell et al. 2017). It is also known that different types of landuse change and land-use intensity have different effects on biodiversity loss, from moderate negative impacts (i.e. little species loss) when land is converted to tree plantations or secondary vegetation, to heavy impacts, when converted to pasture, cropland or urban areas (Newbold et al. 2015). The designation of Protected Areas (PAs) is currently the main conservation strategy to preserve natural ecosystems and protect biodiversity from land-use change, but despite the worldwide overall increase in the percentage of PAs over the last decades, they still fail to adequately address conservation needs in the Anthropocene and under changing climatic conditions (Jenkins \& Joppa 2009, Oliveira et al. 2017). For that reason, other complementary policies are essential to foster the conservation and restoration of BES.

Until very recently, Brazil was setting an example for the rest of the world with its commitments to achieve the sustainable development goals (SDGs) through the reduction of deforestation rates, designation of protected areas and implementation of environmental laws (Loyola 2014, Brancalion et al. 2016, Oliveira et al. 2017). Despite the numerous recent decisions that oppose the global policies and commitments previously ratified by Brazil (Loyola 2014, Vieira et al. 2017), there remain in place a few key pieces of environmental legislation that aim to protect and regulate native vegetation both within public and private properties. For instance, the Atlantic Forest, a global hotspot (Myers et al. 2000), is protected since 2006 by the Atlantic Forest Law (Law n.11.428/2006) (Brasil 2006), which restricts deforestation to very specific situations under a strict licensing process. Another example is the Native Vegetation Protection Law (Law n.12.651/2012) (Brasil 2012, Brancalion et al. 2016), popularly known as the Forest Code. First created in 1934, the Forest Code has gone through changes and the different versions have served varying purposes (Brancalion et al. 2016). It is the main environmental legislation to regulate the maintenance and restoration of native vegetation in private properties (Loyola 2014, Brancalion et al. 2016, Vieira et al. 2017), which encompasses 53\% of the remaining native vegetation in Brazil (Soares-Filho et al. 2014) and up to $70 \%$ of the Atlantic Forest according to recent estimates (Rezende et al. 2018). The Forest Code specifies that every property, apart from the productive areas (i.e. agriculture, silviculture or pasturelands), has to set aside native vegetation in environmentally sensitive areas for biodiversity, soil and water conservation, known as Permanent Protection Areas (PPAs), and a portion of vegetation to ensure the sustainable economic use and conservation of natural resources, known as Legal Reserves (LRs). The PPAs are delimited based on predefined specific rules for several situations such as water springs, rivers, ponds, reservoirs, steep slopes and hilltops. The LRs are defined according to the region in which a private property is located, with varying proportions within different regions in Brazil: in the Amazon, LRs must cover $80 \%$ of forest or $20-35 \%$ of savannas, while in other regions the LRs must reach $20 \%$ of the property, including the PPAs (Brancalion et al. 2016). Nonetheless, the constitutionality of the most recent version of the Forest Code, published in 2012, has been increasingly challenged by the agribusiness in recent years (Loyola 2014, Brancalion et al. 2016, Metzger et al. 2019) and new initiatives have emerged to extinguish the LRs obligation (Metzger et al. 2019). In this critical situation, policy makers could benefit from the support of scientific evidence evaluating the benefits of enforcing the environmental legislation (Loyola 2014, Metzger et al. 2019).

How might different levels of compliance with the legislation affect biodiversity and the provision of ecosystem services in the Cantareira System Protected Area? To address this question, we used various methods - developing a conceptual framework, scenarios and modeling biodiversity and ecosystem services - to illustrate and emphasize key relationships and feedbacks in the complex social-ecological system in our study area. In particular, we investigated how different scenarios of implementation of the Atlantic Forest Law (Law n.11.428/2006) and of the Forest Code (Law 12.651/2012) could affect biodiversity and soil conservation in the Cantareira System Protected Area, composed both of public and private properties, and important for the provision of water for over 9 million people who live in the metropolitan area of the city of São Paulo. Apart from its importance for the provision of water, the area is a biodiversity hotspot (Myers et al. 2000). We expected that a higher level of implementation of the Forest Code and the Atlantic Forest Law would have positive impacts on biodiversity and soil conservation and the related provision of water. In general, we aimed to provide a scientific basis for policy and decisionmakers who are responsible for the implementation of these laws.

\section{Material and Methods}

\section{Methodological approach}

The approach we developed had three steps: (1) the development of a conceptual framework indicating the main pressures and components 
in the system, the relations between them, the current status of the different components, and the delivery of some ecosystem services; (2) the projection of different scenarios of land-use/land-cover (LULC), based on the implementation of the Atlantic Forest Law and the partial or full implementation of the Forest Code; and (3) the assessment of biodiversity conservation and ecosystem services (soil loss and sediment exportation to water bodies, as proxies for soil retention) - delivered in each scenario.

\section{Study area}

The Cantareira System Protected Area (PA) located in southeastern Brazil (hereafter 'Cantareira System PA'), is a sustainable use protected area (IUCN category VI) established by the Sao Paulo State Law 10.111/1998 (Estado de São Paulo 1998). The Cantareira System PA encompasses both public $(13.2 \%)$ and private $(86.8 \%)$ properties in seven municipalities of São Paulo. We also included in the analysis the municipality of Bom Jesus dos Perdões, which is not within the Cantareira System PA boundaries, but it is in the middle of that geographical range (Figure 1). The Cantareira System PA was created mainly for water security purposes, aiming to maintain and improve water quality in the Cantareira Supply System - a large complex of reservoirs that provides freshwater to the metropolitan area of São Paulo city, with over 9 million people (IBGE 2014). The Cantareira System PA consists of four sub-watersheds of the Piracicaba river (Jaguari, Jacarei, Cachoeira and Atibainha) and one of the Alto Tietê river (Juqueri). It comprises five reservoirs and a 2,300 $\mathrm{km}^{2}$ catchment drainage area, with a total water demand of $33 \mathrm{~m}^{3} / \mathrm{s}$ (Water National Agency 2019), providing $46 \%$ of the water supply for the metropolitan area of São Paulo. According to the Köppen classification, the climate is Cwa - humid subtropical: mild and dry winter, and moderately warm with a rainy summer. The Cantareira System PA is located in the Atlantic Forest region, a biodiversity hotspot that has only $26 \%$ of its original vegetation cover remaining (Myers et al. 2000, Rezende et al. 2018). According to the latest assessment, our study area has $35 \%$ forest cover, and $74 \%$ of this vegetation is secondary Atlantic Forest in an intermediate stage of succession (Instituto Florestal 2010).

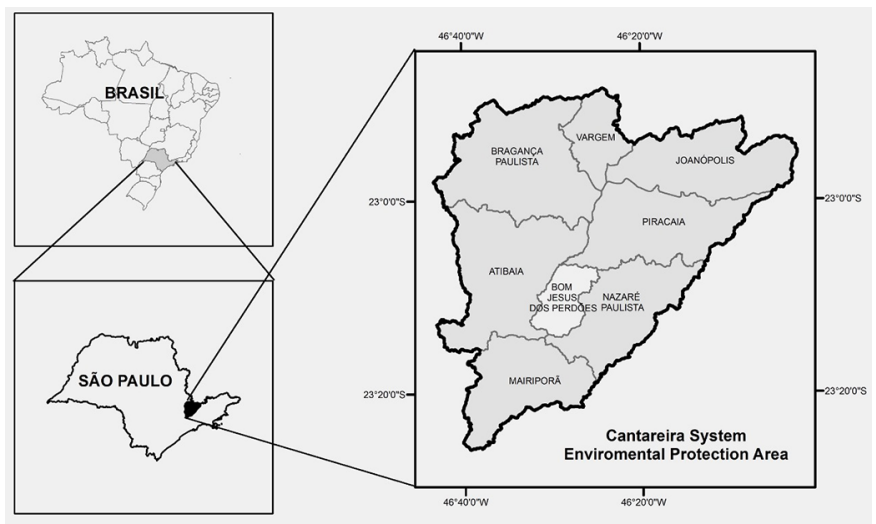

Figure 1. Study area located in the Atlantic Forest of the State of São Paulo, Brazil, including the Cantareira System PA and the municipality of Bom Jesus dos Perdões.

\section{Development of a conceptual framework}

To develop a conceptual framework, we first identified the focal BES elements to target within the study area given the current state of the system, related conjunctures regarding the implementation of public policies, and data availability. Based on these criteria, we selected soil retention together with biodiversity conservation as the elements of most interest for our case study. Secondly, we applied the Driver-Pressure-State-Impact-Response (DPSIR) causal framework (Martins et al. 2012, Tscherning et al. 2012) to identify the various components and dimensions of BES in our study case, including the major driving forces and pressures affecting BES outputs, their relationships, the state of the system at different scales, and the potential impacts of the implementation of public policies. Third, we used the IPBES Nature Futures Framework (NFF, sensu PBL 2018) to classify selected components of the Cantareira System PA related to BES into three different dimensions reflecting how people relate to nature: (i) nature for society, addressing the utilitarian benefits of nature for people; (ii) nature for nature, addressing the intrinsic value of nature functioning and diversity; and (iii) nature for culture, addressing the spiritual and other non-material benefits for people living in harmony with nature. Fourth, we added the direct and indirect drivers and conceptualized how they are connected and how their changes impact biodiversity and the provision of these services. As a last step, we included the social-ecological feedbacks in the system. Given the high complexity of the system and of our conceptual model, we focused primarily on some key-components that we believe are representative of the overall relationships between people and nature within this system (public policies, forest ecosystems, water and land-use).

\section{Land-use change scenarios}

We projected four land-use scenarios to test the effects of deforestation control and forest restoration practices on BES maintenance. We used land-use and cover maps from 1997 and 2017 (Mapbiomas v.4 2017) to analyze land-use cover changes trends and project these to 2050. At one extreme, is the "businessas-usual" scenario (BAU), which assumes that all trends of land-use and cover change observed in the past 20 years will continue until 2050. Then, we built three alternative scenarios: (i) Atlantic Forest Only (AFO) - considering only the implementation of the Atlantic Forest Law, that is, no further deforestation on the current land-use and cover map for 2017; (ii) Partial implementation of the Forest Code (PFC): considering the Atlantic Forest Law implementation and the restoration of Permanent Protected Areas; and (iii) Full implementation of the Forest Code (FFC) - considering the Atlantic Forest Law implementation, and the restoration of both Permanent Protected Areas and Legal Reserves. We built the BAU and the AFO scenarios using the Dinamica EGO software (Soares-Filho et al. 2002). The difference between BAU and AFO scenarios is that AFO assumes no deforestation from 2017 onwards. To build the PFC and FFC scenarios we used AFO scenario as a baseline and then we simulated native vegetation recovery in Permanent Protected Areas (PPA) related to water bodies (riparian areas along rivers and around springs, reservoirs, lakes and lagoons) and in Legal Reserves (LR). The PPA were defined using a 1:50,000 scale hydrographic network (IBGE - Brazilian Institute of Geography and Statistics, topographic maps). For the perennial rivers, lakes and lagoons (with surface smaller than 20 hectares), we used a buffer of $30 \mathrm{~m}$; for the springs, we used a buffer of $50 \mathrm{~m}$; for the large reservoirs (surface 
larger than 20 hectares), a buffer of 100 meters; following what is established by the Forest Code (Brasil 2012). For the LR areas, we employed the map available in the Rural Environmental Registry System (SICAR), which is based on the self-declaratory status of rural properties done by the landowners (see details in Brancalion et al. 2016), and therefore could have underestimated the extent of these areas.

\section{Assessment of biodiversity}

To estimate the current biodiversity conservation value of the areas and assess the impacts of LULC change on biodiversity, we used the approach developed for the GLOBIO3 framework (Alkemade et al. 2009). For this purpose, we considered the LULC categories and the remaining mean species abundance values $\left(\mathrm{MSA}_{\mathrm{LU}}\right)$ detailed in Table 1. The $\mathrm{MSA}_{\mathrm{LU}}$ represents a measure of the species abundance in the different LULCs relative to the pristine or primary vegetation proposed by Alkemade et al. (2009). We attributed an $\mathrm{MSA}_{\mathrm{LU}}$ of 0.7 to the forest remnants in the region, as these are mainly secondary forests intensively exploited in the past, which have been regenerating over many years, but remain different in structure and composition from well preserved forests in the region (Instituto Florestal, 2010). Using the same reasoning, restored forests may take longer than 30 years (our time frame for this study) to have the same MSA as that of today's secondary forests; so, we defined an MSA of 0.5 for restored forests. For all the other categories, we used the $\mathrm{MSA}_{\mathrm{LU}}$ values suggested by Alkemade et al. (2009).

\section{Assessment of ecosystem services}

For the ES assessment, we compared the potential soil loss and sediment exportation into streams among the scenarios. To calculate the soil loss on a 30x30 m spatial resolution, we used the Sediment Delivery Ratio (SDR) module from InVEST 3.7.0, which is a spatially explicit model that calculates the average annual amount of soil loss for each pixel. As a result, the SDR estimated the sediment yield into streams and the annual loss of soils in tons. The SDR is based on the Universal Soil Loss Equation (Wischmeier \& Smith 1978).

$$
A=R * K * L S * C * P
$$

In which: $A$ is the average loss of soil per unit area $\left(\mathrm{t} \mathrm{ha}^{-1}\right.$ year $\left.{ }^{1}\right) ; R$ is the rainfall erosivity factor $\left(\mathrm{MJ} \mathrm{mm} \mathrm{ha}{ }^{-1} \mathrm{~h}^{-1}\right.$ year $\left.{ }^{-1}\right) ; K$ is the soil erodibility factor $\left(\mathrm{t} \mathrm{h} \mathrm{MJ}{ }^{-1} \mathrm{~mm}^{-1}\right) ; L S$ is the topographic factor (dimensionless); $C$ is the soil use and management factor (dimensionless) and $P$ is the conservation dimension factor (dimensionless). To calculate the $L S$-factor, we used a $30-\mathrm{m}$ digital elevation model (DEM) obtained from EMBRAPA - Brazilian Agricultural Research Company/Satellite Monitoring. The $R$-factor was obtained from Neto (1995). The $K$ factor was estimated using global data (Harmonized World Soil Database -HWSD - FAO 2012) and values obtained from the literature (Saad et al. 2016, Mannigel et al. 2002, Miteva et al. 2014) (Table 2). The soil types were obtained from Rossi (2017). The $C$-factor was also estimated from the literature, including studies in the same biome (Table 3) (Ruhof et al. 2006, Machado et al. 2009, Silva et al. 2010, Barbosa 2012, Gomez 2012, Silva et al. 2012, Thompson \& Fidalgo 2013, Xavier et al. 2013, Ribeiro 2015, Saad et al. 2016). The $P$-factor is related to the conservation practices used in the region for each use and land cover class, and since the region does not currently include conservation practices, we attributed the value 1 to all land-uses.

\section{Results}

\section{Conceptual framework}

Based on our DPSIR and the Nature's Future Frameworks we developed the conceptual framework presented in Figure 2.

\section{Land-use scenarios}

Pastureland is the predominant land-use class in the Current situation ( $48 \%$ of total area), but its extent tended to decrease under the forest conservation (AFO) and restoration (PFC and FFC) scenarios, reducing to $30.2 \%$ in the most optimistic simulation. Natural forests were the second largest land-use type (35.4\% of total area) and may

Table 1. Land-use / land-cover (LULC) categories and Mean Species Abundance values considered for modeling biodiversity in the different scenarios. Adapted from Alkemade et al. (2009).

\begin{tabular}{|c|c|c|}
\hline Land-use category & Description & $\begin{array}{c}\text { Mean Species } \\
\text { Abundance per land-use } \\
\text { value (MSALU) }\end{array}$ \\
\hline Natural forest & $\begin{array}{l}\text { Secondary patches of Atlantic Forest that are either remnants heavily exploited in the } \\
\text { past but never cleared, or second-growth forests }\end{array}$ & 0.7 \\
\hline Restored forest & $\begin{array}{l}\text { Atlantic Forest patches in different stages of secondary succession growing on former } \\
\text { farmland as a result of active restoration or natural regeneration in areas set aside after } \\
\text { legal requirement }\end{array}$ & 0.5 \\
\hline Silviculture & $\begin{array}{c}\text { Pure stands of Eucalyptus spp. or Corymbia spp. planted for commercial exploitation in } \\
\text { areas originally covered by Atlantic Forest }\end{array}$ & 0.2 \\
\hline Pastureland & $\begin{array}{c}\text { Artificial grasslands maintained for livestock in areas originally covered by Atlantic } \\
\text { Forest }\end{array}$ & 0.1 \\
\hline
\end{tabular}


Dib, V. et al.

Table 2. Soil Types and $K$-Factor values considered for modeling soil loss and sediment exportation to water in the different scenarios.

\begin{tabular}{lc}
\hline Soil Type & $\boldsymbol{K}$-Factor \\
\hline Dystrophic red-yellow argisol & 0.036 \\
Dystrophic red-yellow latosol & 0.015 \\
Dystrophic yellow latosol & 0.03 \\
Eutrophic red-yellow argisol & 0.03 \\
Haplic Cambisol & 0.03 \\
Humic Cambisol & 0.035 \\
Melanic gleysol & 0.026 \\
\hline
\end{tabular}

Table 3. Land-use / land-cover categories and $C$-Factor values considered for modeling soil loss and sediment exportation to water in the different scenarios.

\begin{tabular}{lc}
\hline LULC class & $\boldsymbol{C}$-Factor \\
\hline Natural forest & 0.0001 \\
Pastureland & 0.052 \\
Restored forest & 0.0001 \\
Silviculture & 0.0007 \\
Urban area & 0.0375 \\
Agriculture & 0.26 \\
\hline
\end{tabular}

increase to $43.1 \%$, under the scenario of Full implementation of the Forest Code. These tendencies were accompanied by a decrease in silviculture and an increase in forest restoration, as well as a slight increase in agricultural areas (Table 4). The native forest of the Cantareira System PA might be reduced from 35.4\% (its current area) to $34.5 \%$ (BAU scenario) by 2050 if the current trends continue (Table 4). Most of these trends are visually distinguishable on the land-use maps presented in Figure 3 and Figure 4.

\section{Consequences for BES}

Overall native forest cover (natural forest remnants and restored forests) increased consistently, and markedly, as we shifted from the BAU scenario (34.5\% of total area) to the scenario of Full Implementation of the Forest Code (52.5\% of total area) (Figure 5-A). The same pattern was observed for Mean Species Abundance (MSA), that ranged from 0.29 (BAU) to 0.40 (FFC) (Figure 5-B). The potential soil loss decreased from the Business as usual scenario (16.32 million tons/yr) to the scenario of Full Implementation of the Forest Code (11.73 million tons/yr), as did the amount of sediment exported into water bodies (1.98 to 1.00 million tons/yr) (Figure 5 - C and D).

Our results suggested an MSA decrease under the BAU scenario relative to the Current situation. On the other hand, the MSA increased from $29 \%$ (BAU) to $35 \%$ (AFO) with the implementation of the Atlantic Forest Law (AFO scenario) and to $40 \%$ with the partial

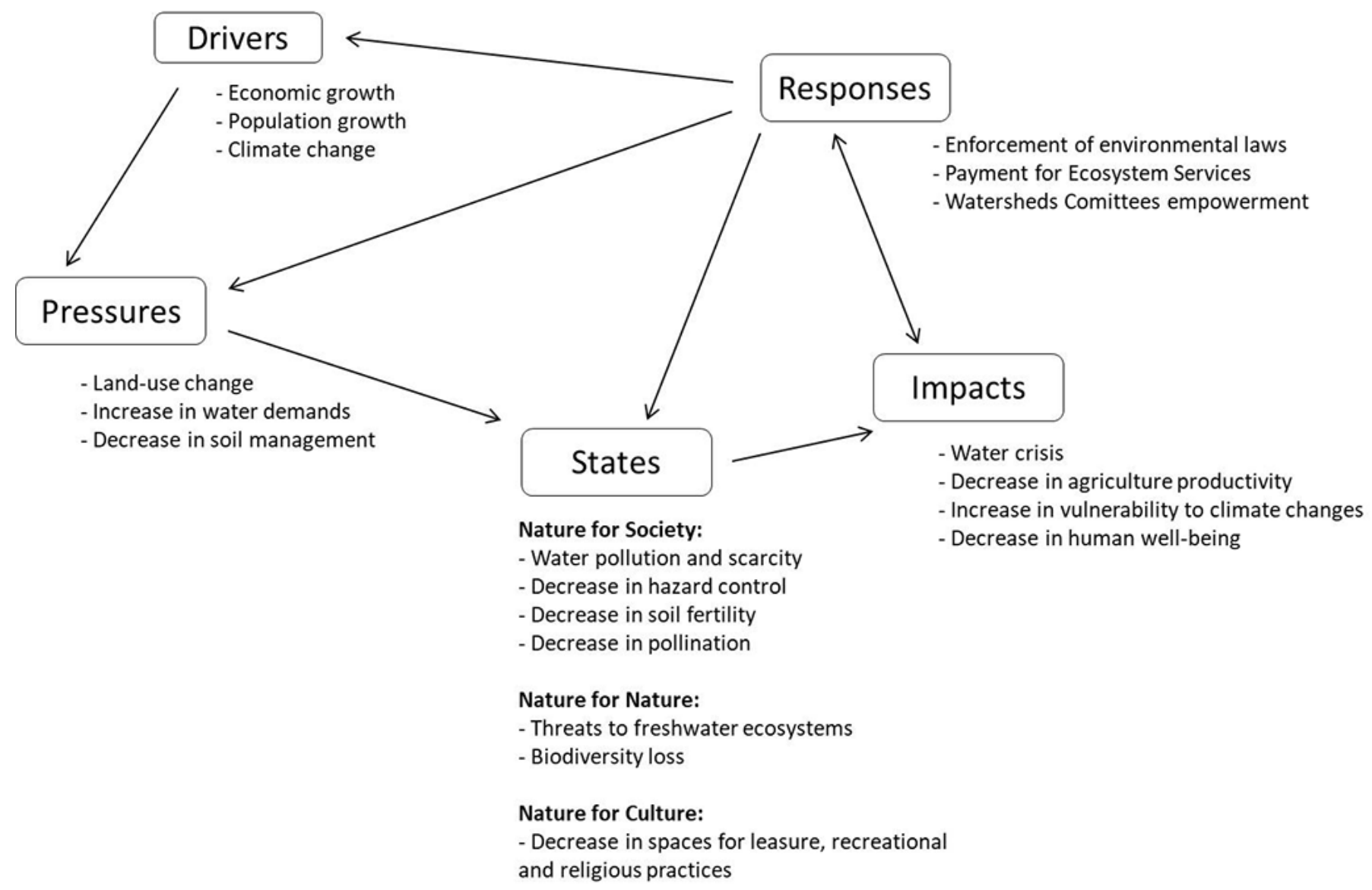

Figure 2. Application of DSPIR framework to the Cantareira System Protected Area, São Paulo, Brazil. 
Drivers of change in biodiversity and ecosystem services in the Cantareira System Protected Area

Table 4. Land-use and land-cover (LULC) of the current situation (2017) and future scenarios (2050) in the Cantareira System Protected Area, São Paulo, Brazil.

\begin{tabular}{lcccccccccc}
\hline \multirow{2}{*}{ LULC class } & \multicolumn{2}{c}{$\mathbf{2 0 1 7}$ (CUR) } & \multicolumn{2}{c}{$\mathbf{2 0 5 0}$ (BAU) } & \multicolumn{2}{c}{$\mathbf{2 0 5 0}$ (AFO) } & \multicolumn{2}{c}{$\mathbf{2 0 5 0}$ (PFC) } & \multicolumn{2}{c}{$\mathbf{2 0 5 0}$ (FFC) } \\
\cline { 2 - 12 } & $\mathbf{( h a )}$ & $\mathbf{( \% )}$ & $\mathbf{( h a )}$ & $\mathbf{( \% )}$ & (ha) & $\mathbf{( \% )}$ & (ha) & (\%) & (ha) & (\%) \\
\hline Natural forest & 93,869 & 35.4 & 91,3 & 34.5 & 93,87 & 35.4 & 114,23 & 43.1 & 114,23 & 43.1 \\
Pastureland & 127,22 & 48.0 & 110,7 & 41.8 & 98,22 & 37.1 & 83,037 & 31.4 & 80,06 & 30.2 \\
Restored forest & 0 & 0.0 & 0 & 0.0 & 20,36 & 7.7 & 20,509 & 7.7 & 24,938 & 9.4 \\
Silviculture & 20,449 & 7.7 & 31,53 & 11.9 & 21,99 & 8.3 & 19,431 & 7.3 & 18,329 & 6.9 \\
Urban area & 10,501 & 4.0 & 16,43 & 6.2 & 16,03 & 6.1 & 14,291 & 5.4 & 14,188 & 5.4 \\
Agriculture & 5,759 & 2.2 & 8,592 & 3.2 & 8,146 & 3.1 & 7,684 & 2.9 & 7,446 & 2.8 \\
\hline
\end{tabular}

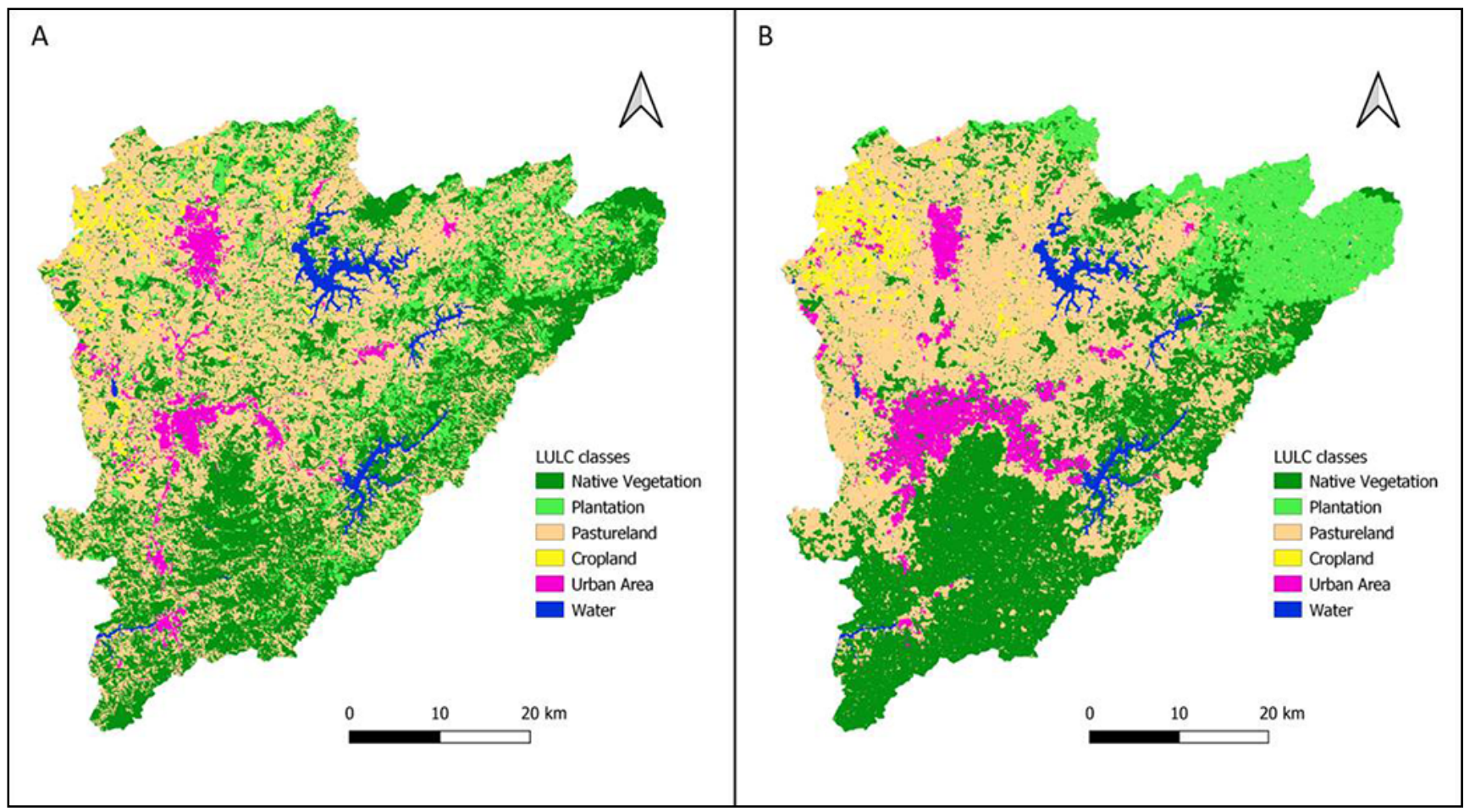

Figure 3. Cantareira System PA maps representing Land Use and Land Cover in (A) the Current situation (Mapbiomas v.4 2017) and (B) the Business as Usual scenario (projection for 2050).

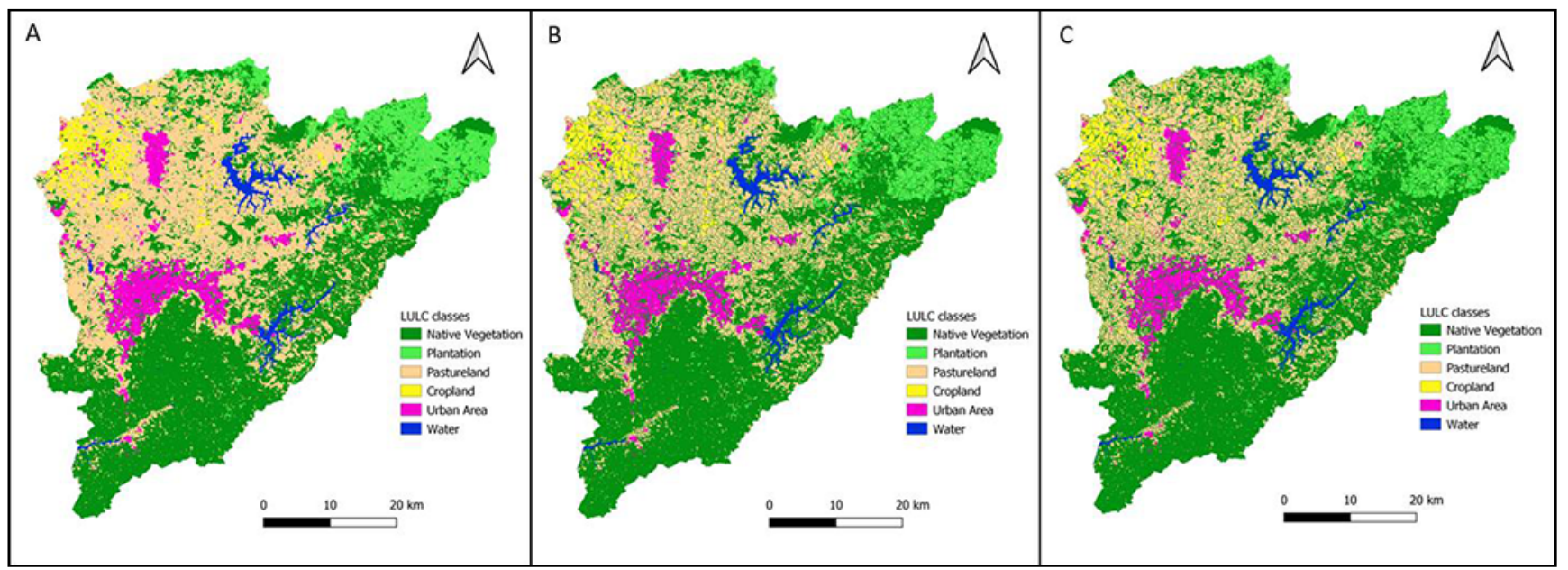

Figure 4. Cantareira System PA maps representing Land-use and Land Cover alternative scenario projections for 2050: (A) AFO - Atlantic Forest Only; (B) PFC - Partial Forest Code; and (C) FFC - Full Forest Code implementation (restoration of Permanent Protection Areas and Legal Reserves). 
Dib, V. et al.
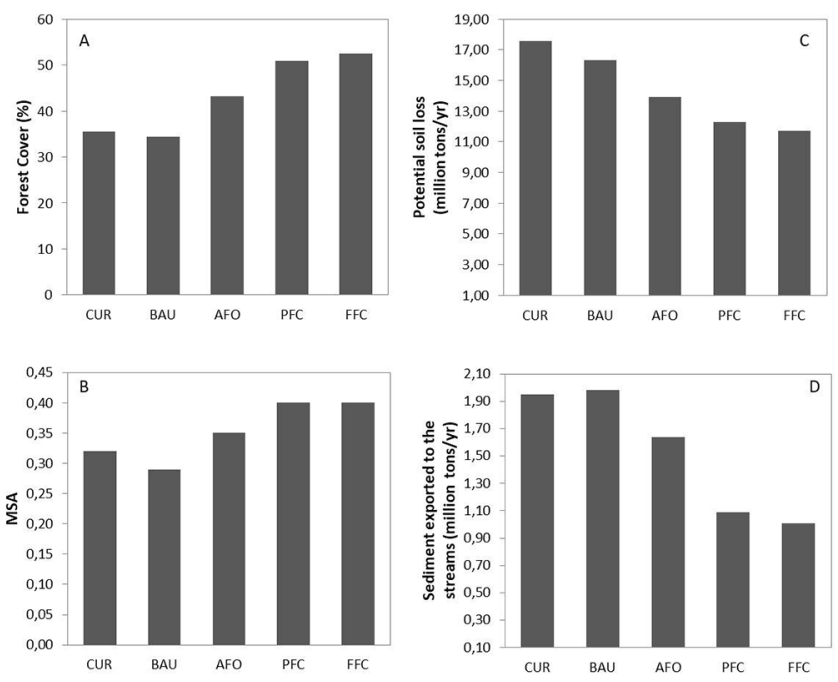

Figure 5. Trends of change in forest cover, biodiversity and soil conservation for the current situation and for future scenarios in the Cantareira System PA. (A) Forest cover percentage (native and restored forests); (B) Mean Species Abundance-MSA; (C) Potential soil loss; (D) Amount of sediment exported to water bodies. $\mathrm{CUR}=$ Current situation; $\mathrm{BAU}=$ Business As Usual; $\mathrm{AFO}=$ Atlantic Forest protection law Only; PFC = Partial Forest Code implementation (restoration of Permanent Protection Areas); FFC $=$ Full Forest Code implementation (restoration of Permanent Protection Areas and Legal Reserves).

or full implementation of the Forest Code. We did not observe marked differences in MSA when comparing PFC an FFC scenarios (Figure 5-B). Considering the soil retention assessment, our results showed a tendency of decrease in soil loss and increase in sediment exportation to water, comparing BAU to the Current situation. Also, our projections showed a decrease of soil loss in all alternative scenarios in relation to the BAU (AFO: reduction of $24.70 \%$; PFC: reduction of $34.70 \%$; FFC: reduction of $38.12 \%$ ). The results for sediment exported into water bodies exhibited the same pattern. However, the reduction was even more marked in the restored scenarios (AFO: reduction of $27.47 \%$; PFC: reduction of $55.06 \%$; FFC: reduction of $59.28 \%$ ). This suggested that the sediment retention service provided by the landscape was more efficient under scenarios in which PPA and RL were restored.

\section{Discussion}

The development and the evaluation of possible scenarios suggested that we can expect an overall increase of BES under higher levels of compliance to Brazilian environmental legislation, reinforcing their importance for accomplishing Brazil's national commitments to achieve the SDGs (Loyola 2014). Our study predicted that forest cover will increase up to $48 \%$ when comparing the Business as usual (BAU) with the most optimistic scenario (FFC), with a resulting improvement in values of Mean Species Abundance and the reduction in potential soil loss and exportation of sediments into streams, with likely positive impacts on water quality.

Based on the DPSIR framework, our conceptual model included, in a broad way, the current trends of the economic system and human population growth as the main indirect drivers affecting large-scale water quantity and quality, as well as the maintenance of biodiversity within our study area. According to this perspective, these indirect drivers influence the dynamics of other more direct drivers such as the demand for this resource (total and per capita) by the inhabitants both within the Cantareira System Protected Area and in the city of Sao Paulo. In the same direction, it is likely that a greater proportion of the native vegetation within our study area will be susceptible to conversion to other uses, such as urban, agricultural or silvopastoral, affecting both LULC proportions and soil management. Considering that, in recent years, trends in precipitation and temperature have shown significant anomalies (Nobre et al. 2016), climate change is likely to be another factor of great importance in the Cantareira System PA. All these factors, both direct and indirect, were established as the main potential drivers of change in the state of nature, encompassing different dimensions of our interest: the availability of good quality water for human consumption, agricultural and industrial use (nature for society dimension); the maintenance of stable hydrological cycles and healthy freshwater ecosystems (nature for nature dimension); and the recreation, education, leisure, and religious associated aspects (nature for culture dimension). In parallel, these drivers are also seen as the main causes of loss of biodiversity in our study area, affecting both the abundance of species of different taxa, and the services that emerge from them in all the dimensions (Nature for Society, for Nature, and for Culture). We identified the Forest Code and the Atlantic Forest Law as external factors (i.e., public policies) whose application in the near future can play an important role in regulating direct and indirect drivers of change, and helping to conserve the system, through their influence on the maintenance of native vegetation cover.

Apart from the restoration outputs resulting from the partial or full implementation of the Forest Code, our results also highlighted the potential contribution of natural regeneration within our study region, revealed by the increased percentage of natural forest cover in all scenarios except for the BAU. Studies evaluating the potential of tropical secondary forests state that international conservation and restoration commitments depend on the regeneration of forests on abandoned areas (Brancalion et al. 2019, Crouzeilles et al. 2019). Despite the limited habitat quality and provision of ecosystem services, there is consistent evidence demonstrating the value of secondary forests (Rozendaal et al. 2019). Putting together all types of forests, even the Business as Usual scenario shows a small increase compared to the Current situation, in that case, related to an increase in silviculture. The more optimistic scenarios showed an overall large increase in forested area, characterized by a slight decrease in silviculture outweighed by significant increases in restored areas necessary to comply with the Forest Code and also by significant increases in natural forest remnants regenerating outside of the areas required to be restored by the Forest Code, probably resulting from the abandonment of marginal agricultural areas of low productivity.

The land that needs to be restored within the Cantareira System Protected Area corresponds to 20,509 ha of riparian forests and 4,429 ha outside of riparian forests; a total of 
24,938 ha currently being used irregularly for the production of livestock, crops and wood. Besides the irregular aspect of this current land-use, it also negatively affects the price of the land (which is lower when a landowner does not comply with the law), threatens biodiversity conservation, and compromises the provision of ecosystem services, including water to a large human population. The average cost of forest restoration in the Atlantic Forest ranges from $\mathrm{R} \$ 0.2$ to 21.3 thousand Brazilian reais per hectare (Benini \& Adeodato, 2017, Tymus et al. 2018), depending on the conditions of the site and the characteristics of the landscape. Considering that the area has a large natural forest cover, it may have an overall high natural regeneration potential. For this reason, it is reasonable to assume that the average cost for restoring a hectare is around $\mathrm{R} \$ 10 \mathrm{k}$, summing to nearly $\mathrm{R} \$ 250$ million Brazilian reais. There are recent developments towards cost-effective restoration of the Legal Reserves in degraded areas of the Atlantic Forest that provide financial return to offset at least part of the costs of converting degraded lands back into natural forests (Amazonas et al. 2018a, Brancalion et al. 2019). In protected areas important to water production such as our study site, these mixed forests could be even used as an alternative to traditional silviculture since they result in less drying of soils (Amazonas et al. 2018b).

We observed a small decrease in native forest cover in the BAU scenario, compared to the Current situation, coupled with some conversion of pastureland into silviculture. Therefore, the resulting overall forest cover increase was predominantly due to silviculture expansion, and it resulted in soil loss reduction. Despite that, the amount of sediment exported into water bodies was greater in the BAU scenario, which may be explained by a loss of riparian vegetation. When we compared the BAU with the more optimistic scenarios of increasingly higher forest cover, we observed an increase in sediment retention coupled with higher forest cover. Moreover, in the scenarios in which the riparian forests are restored, the sediment retention ecosystem service is further improved since less sediment is exported to the water. The scenario of Partial implementation of the Forest Code, for example, where riparian forests are restored, soil loss is reduced in $34 \%$ and sediment exportation is reduced in $55 \%$. The major sources of sediment pollution in the Cantareira System PA are the pasturelands and croplands (Richards et al. 2017), especially in those areas with insufficient or absent sustainable management practices. Forest conservation and restoration can substantially reduce erosion effects (Zaimes et al. 2008). Also, it is expected that this vegetation reduces siltation and pollution, by trapping a large fraction of the soil particles and runoff originating from arable land (Dosskey et al. 2010, Zhang et al. 2010). These benefits reduce costs associated with water treatment and dredging.

The higher soil retention and lower sediment exportation to streams in the optimistic scenarios compared to the Current situation and to the BAU scenario were probably related to the capacity of forests to counteract the detrimental effects of soil erosion downslope of the areas of sediment production as well as to act as a buffer to water bodies, protecting against stream bank erosion (McKergow et al., 2003; Zaimes et al., 2008; Zaimes and Schultz, 2015) and against pollution. Furthermore, the Atlantic Forest areas always maintain litterfall over the soil and the Leaf Area Index is constant, which means that the soil is covered during the entire year. The higher the Leaf Area Index, the greater the interception of water by leaves, preventing further increases in runoff and preventing soil detachment by raindrop impact. Another important point is that forested areas generally have larger water infiltration rate than cropped areas due soil compaction and surface crust formation as a result of heavy machinery use in cropland and the lack of sustainable practices for soil management (Gomes et al. 2019). These results thus strongly suggest that the full implementation of the Forest Code could improve water quality and availability in the Cantareira System Protected Area.

Reaching a future in which the land-use in the Cantareira System Protected Area resembles our most optimistic scenario requires efforts and resources, including setting aside areas and restoring native vegetation, to promote the land-use changes necessary to comply with the Forest Code. Investing in the implementation of the Forest Code may translate in avoided costs of water treatment and dredging. Also, these changes are likely to result in significant biodiversity gains (MSA increase). Moreover, the value of land may increase once landowners comply with the Forest Code (Pires et al. 2019). By modeling the impacts of land-use change in each scenario on biodiversity and ecosystem services provision, our aim was to inform relevant stakeholders about the consequences of an incomplete implementation of the land-use changes necessary to comply with the Forest Code. We hope this information convinces and mobilizes society for the implementation of land-use changes that clearly improve biodiversity conservation, the functioning of ecosystems and the related provisioning of ecosystem services important for human well-being. Our results emphasize the urgent need to implement/ enforce the two major regulating instruments in the Atlantic Forest biome: the Forest Code and the Atlantic Forest Law.

\section{Acknowledgements}

We thank the São Paulo Research Foundation (FAPESP) for supporting the "São Paulo School of Advanced Science on Scenarios and Modelling on Biodiversity and Ecosystem Services to Support Human Well-Being”. Jan Daněk acknowledges support from the Specific Academic Research project "Research on social and environmental innovations", grant nr VS 260471 and from the Technology Agency of the Czech Republic, grant nr TL02000520.

\section{Authors' Contributions}

Viviane Dib: Substantial contribution in the concept and design of the study; Substantial contribution in the concept and design of the study; Contribution to data collection; Contribution to data analysis 
and interpretation; Contribution to critical revision, adding intelectual content.

Marco Aurélio Nalon: Substantial contribution in the concept and design of the study; Contribution to data collection; Contribution to data analysis and interpretation; Contribution to manuscript preparation.

Nino Tavares Amazonas: Substantial contribution in the concept and design of the study; Contribution to data collection; Contribution to data analysis and interpretation; Contribution to manuscript preparation; Contribution to critical revision, adding intelectual content.

Cristina Yuri Vidal: Substantial contribution in the concept and design of the study; Contribution to manuscript preparation; Contribution to critical revision, adding intelectual content.

Iván A. Ortiz-Rodríguez: Substantial contribution in the concept and design of the study; Contribution to manuscript preparation; Contribution to critical revision, adding intelectual content.

Jan Daněk: Substantial contribution in the concept and design of the study; Contribution to data analysis and interpretation; Contribution to manuscript preparation; Contribution to critical revision, adding intelectual content.

Maíra Formis de Oliveira: Substantial contribution in the concept and design of the study; Contribution to data collection; Contribution to data analysis and interpretation; Contribution to manuscript preparation; Contribution to critical revision, adding intelectual content.

Paola Alberti: Substantial contribution in the concept and design of the study; Contribution to manuscript preparation.

Rafaela Aparecida da Silva: Substantial contribution in the concept and design of the study; Contribution to manuscript preparation.

Taciana Figueiredo Gomes: Substantial contribution in the concept and design of the study; Contribution to data collection; Contribution to data analysis and interpretation; Contribution to manuscript preparation; Contribution to critical revision, adding intelectual content.

Raíza Salomão Precinoto: Contribution to data collection; Contribution to data analysis and interpretation; Contribution to manuscript preparation.

\section{Conflicts of Interest}

The authors declare that they have no conflict of interest related to the publication of this manuscript.

\section{Ethics}

The authors declare that they have complied with the guidelines established by the ethics committees of their respective research institutions.

\section{Data availability}

Additional data regarding the mathematical models used will be archived in the in public data repository "Sistema de Informação Ambiental do Programa Biota/Fapesp/SinBiota".

\section{References}

ALKeMADE, R., OORSCHOT, M. Van, Miles, L., NELlEMANN, C., BAKKENES, M. \& BRINK, B. ten. 2009. GLOBIO3 : A Framework to Investigate Options for Reducing Global Terrestrial Biodiversity Loss. Ecosystems 12374-390.
AMAZONAS, N.T., FORRESTER, D.I., SILVA, C.C., ALMEIDA, D.R.A. \& BRANCALION, P.H.S. 2018a. High diversity mixed plantations of Eucalyptus and native trees: an interface between production and restoration for the tropics. For. Ecol. Manage. 417(November 2017):247-256.

AMAZONAS, N.T., FORRESTER, D.I., OLIVEIRA, R.S. \& BRANCALION, P.H.S. 2018b. Combining Eucalyptus wood production with the recovery of native tree diversity inmixed plantings: Implications for water use and availablity. For. Ecol. Manage. 418 (January 2018):34-40.

BENINI, R. de M. \& ADEODATO, S. 2017. Economia da restauração florestal.

BRANCALION, P.H.S., GARCIA, L.C., LOYOLA, R., RODRIGUES, R.R., PILLAR, V.D. \& LEWINSOHN, T.M. 2016. A critical analysis of the Native Vegetation Protection Law of Brazil (2012): Updates and ongoing initiatives. Nat. e Conserv. 141-15.

BRANCALION, P.H.S., NIAMIR, A., BROADBENT, E., CROUZEILLES, R., BARROS, F.S.M., ZAMBRANO, A.M.A., BACCINI, A., ARONSON, J., GOETZ, S., REID, J.L., STRASSBURG, B.B.N., WILSON, S. \& CHAZDON, R.L. 2019. Global restoration opportunities in tropical rainforest landscapes. Sci. Adv. 5(July):1-12.

BRASIL. 2006. Lei ${ }^{\circ} 11.428$, de 22 de dezembro de 2006. Dispõe sobre a utilização e proteção da vegetação nativa do Bioma Mata Atlântica e dá outras providências.

BRASIL. 2012. Lei n ${ }^{\circ} 12.651$, de 25 de maio de 2012. Dispõe sobre a proteção da vegetação nativa e dá outras providências.

CARDINALE, B.J., DUFFY, J.E., GONZALEZ, A., HOOPER, D.U., PERRINGS, C., VENAIL, P., NARWANI, A., MACE, G.M., TILMAN, D., A.WARDLE, D., KINZIG, A.P., DAILY, G.C., LOREAU, M., GRACE, J.B., LARIGAUDERIE, A., SRIVASTAVA, D.S. \& NAEEM, S. 2012. Biodiversity loss and its impact on humanity. Nature 489(7415):326-326.

CEOLA, S., LAIO, F., \& MONTANARI, A. 2015. Human-impacted waters: New perspectives from global high-resolution monitoring. Water Resources Research, 51(9): 7064-7079.

CROUZEILLES, R. et al. 2019. There is hope for achieving ambitious Atlantic Forest restoration commitments. Perspect. Ecol. Conserv. 17(2):80-83.

DÍAZ, S. et al. 2015. The IPBES Conceptual Framework - connecting nature and people. Curr. Opin. Environ. Sustain. 1-16.

DOSSKEY, M.G., VIDON, P., GURWICK, N.P., ALLAN, C.J., DUVAL, T.P \& LOWRANCE, R. 2010. THE ROLE OF RIPARIAN VEGETATION IN PROTECTING AND IMPROVING CHEMICAL WATER QUALITY IN STREAMS 1. J. Am. Water Resour. Assossiation 46(2):261-277.

ESTADO DE SÃO PAULO. 1998. Lei Estadual n 10.111, 4 de dezembro de 1998. Declara Área de Proteção Ambiental - APA o "Sistema Cantareira".

FAO/IIASA/ISRIC/ISS-CAS/JRC, 2012. Harmonized World Soil Database (version 1.2). FAO, Rome, Italy and IIASA, Laxenburg, Austria.

GÓMEZ, Javier Dario Pulido. Estimativa de erosão pela Equação Universal de Perda de Solo (USLE) e transferência de sedimentos para todo território Brasileiro. 2012. Tese (Doutorado em Solos e Nutrição de Plantas) - Escola Superior de Agricultura Luiz de Queiroz, Universidade de São Paulo, São Paulo.

GOMES, T.F., DE BROEK, M. Van, GOVERS, G.; SILVA, R.W.C. 2019. Runoff, soil loss, and sources of particulate organic carbon delivered to streams by sugarcane and riparian areas: An isotopic approach. Catena. (181).

GRIZZETTI, B., LANZANOVA, D., LIQUETE, C., REYNAUD, A. \& CARDOSO, A.C. 2016. Environmental Science \& Policy Assessing water ecosystem services for water resource management. Environ. Sci. Policy 61194-203

HADDAD, N.M. et al. 2015. Habitat fragmentation and its lasting impact on Earth's ecosystems. Science (80-. ). (March):1-9.

IBGE. 2014. Instituto Brasileiro de Geografia e Estatística (2014). Demographic census 2010 and estimates for 2014Title.

INSTITUTO FLORESTAL, 2010. Inventário Florestal do Estado de São Paulo.

IPBES. 2018. The IPBES regional assessment report on biodiversity and ecosystem services for the Americas J. Rice, C. S. Seixas, M. E. Zaccagnini, M. Bedoya-Gaitán, \& N. Valderrama, eds. 
IPBES. 2019. Summary for policymakers of the global assessment report on biodiversity and ecosystem services of the Intergovernmental Science-Policy Platform on Biodiversity and Ecosystem Services.

ISBELL, F., CALCAGNO, V., HECTOR, A., CONNOLLY, J., HARPOLE, W.S., REICH, P.B., SCHERER-LORENZEN, M., SCHMID, B., TILMAN, D., VAN RUIJVEN, J., WEIGELT, A., WILSEY, B.J., ZAVALETA, E.S. \& LOREAU, M. 2011. High plant diversity is needed to maintain ecosystem services. Nature 477(7363): 199-202.

IUFRO. 2018. Forest and Water on a Changing Planet: Vulnerability, Adaptation and Governance opportunities. A Global Assessment Report. IUFRO Worl ed. International Union of Forest Research Organizations (IUFRO), Vienna.

JENKINS, C.N. \& JOPPA, L. 2009. Expansion of the global terrestrial protected area system. Biol. Conserv. 142(10):2166-2174.

JENNINGS, M.D., HOEKSTRA, J., HIGGINS, J. \& BOUCHER, T. 2008 A comparative measure of biodiversity based on species composition. Biodivers. Conserv. 17833-840.

JOLY, C.A., METZGER, J.P. \& TABARELLI, M. 2014. Experiences from the Brazilian Atlantic Forest : ecological findings and conservation initiatives. New Phytol. 204459-473.

JOLY, C.A., METZGER, J.P., TABARELLI, M., 2014. Experiences from the Brazilian Atlantic Forest : ecological findings and conservation initiatives. New Phytol. 204, 459-473.

LAURANCE, W.F. 2009. Conserving the hottest of the hotspots. Biol. Conserv. $142(6): 1137$.

LOYOLA, R. \& BINI, L.M. 2015. Water shortage: a glimpse into the future. Nat. Conserv. 131-2.

LOYOLA, R. 2014. Brazil cannot risk its environmental leadership. Divers. Distrib. 20(12):1365-1367.

MACHADO, Marley L. et al. Levantamento sistemático dos fatores da Equação Universal de Perdas de Solos (USLE) para o delineamento de áreas com potencial erosivo da bacia PN1-IGAM, Minas Gerais (resultados parciais). Simpósio Brasileiro De Sensoriamento Remoto, Natal, v. 14, p. 7733-7739, 2009.

MALHI, Y., GARDNER, T. a., GOLDSMITH, G.R., SILMAN, M.R. \& ZELAZOWSKI, P. 2014. Tropical Forests in the Anthropocene. Annu. Rev. Environ. Resour. 39125-159.

MANNIGEL, A. R. et al. Fator erodibilidade e tolerância de perda dos solos do Estado de São Paulo. Acta Scientiarum. Agronomy, v. 24, p. 1335-1340, 2008.

MAPBIOMAS 2017 MapBiomas Project - 4.0 Collection of Annual Series of Brazil Land Use Cover Maps, access on Sep.20 ${ }^{\text {th }}$, 2019. http://plataforma. mapbiomas.org/map\#coverage

MARTINS, J.H., CAMANHO, A.S. \& GASPAR, M.B. 2012. A review of the application of driving forces e pressure e State e impact e Response framework to fisheries management. Ocean Coast. Manag. 69 (0): 273-281.

MCGILL, B. 2015. Land use matters. Nature 520(7545):38-39.

MCKERGOW, L.A., WEAVER, D.M., PROSSER, I.P., GRAYSON, R.B. \& REED, A.E.G. 2003. Before and after riparian management : sediment and nutrient exports from a small agricultural catchment, Western Australia. J. Hydrol. 270253-272.

MEA. 2005. Millennium Ecosystem Assessment: Current State \& Trends Assessment. Freshwater Ecosystem Services (Chapter 7).

METZGER, J.P., BUSTAMANTE, M.M.C., FERREIRA, J., FERNANDES, G.W., LIBRÁN-EMBID, F., PILLAR, V.D., PRIST, P.R., RODRIGUES, R.R., VIEIRA, I.C.G. \& OVERBECK, G.E. 2019. Why Brazil needs its Legal Reserves Why Brazil needs its Legal Reserves. Perspect. Ecol. Conserv. (August):

MITEVA, D. A. et al. Hydrological model parameters for the Invest water quality models applied to the Brazilian Cerrado. The Nature Conservancy, 2014.

MYERS, N., MITTERMEIER, R.A., MITTERMEIER, C.G., DA FONSECA, G.A. \& KENT, J. 2000. Biodiversity hotspots for conservation priorities. Nature 403(6772):853-858.

NETO, J.L.S. 1995. A erosividade das chuvas no estado de São Paulo. Rev. do Dep. Geogr. 9(1):35-49.
NEWBOLD, T. et al. 2015. Global effects of land use on local terrestrial biodiversity. Nature.

OLIVEIRA, U., SOARES-FILHO, B.S., PAGLIA, A.P., BRESCOVIT, A.D., DE CARVALHO, C.J.B., SILVA, D.P., REZENDE, D.T., LEITE, F.S.F., BATISTA, J.A.N., BARBOSA, J.P.P.P., STEHMANN, J.R., ASCHER, J.S., DE VASCONCELOS, M.F., DE MARCO, P., LÖWENBERG-NETO, P., FERRO, V.G. \& SANTOS, A.J. 2017. Biodiversity conservation gaps in the Brazilian protected areas. Sci. Rep. 7(1):1-9.

PBL 2018 Report on the Workshop "Next Steps in Developing Nature Futures". PBL Netherlands Environmental Assessment Agency, The Hague.

PEREIRA, H.M. et al. 2010. Scenarios for global biodiversity in the 21 st century. Science (80-. ). 330(6010):1496-1501

PIRES, A.P.F., FARJALLA, V.F., FARIA, B.M., RODRIGUEZ, D.A., GOMES, E.A.T., SANTOS, E.C., SODRÉ, F.N.G.A.S., SABINO, J., ESPÉCIE, M.A., PINHEIRO, M.R.C., RIBEIRO, M.L., BOZELLI, R.L., PANOSSO, R.F., MORMUL, R.P., BARTHEM, R., SCOFIELD, V. \& DIB, V. 2019 Sumário para Tomadores de Decisão (STD) do Relatório Temático Água: biodiversidade, serviços ecossistêmicos e bem estar humano no Brasil.

REZENDE, C.L., SCARANO, F.R., ASSAD, E.D., JOLY, C.A., METZGER, J.P., STRASSBURG, B.B.N., TABARELLI, M., FONSECA, G.A. \& MITTERMEIER, R.A. 2018. From hotspot to hopespot : An opportunity for the Brazilian Atlantic Forest. Perspect. Ecol. Conserv. 16(4):208-214.

RICHARDS, R.C., KENEDDY, C.J., LOVEJOY, T.E. \& BRANCALION, P.H.S. 2017. Considering farmer land use decisions in efforts to "scale up" Payments for Watershed Services.pdf. Ecosyst. Serv. 23238-247.

ROSSI, M. 2017 Mapa pedológico do Estado de São Paulo: revisado e ampliado. São Paulo: Instituto Florestal, 2017. V1, 118p.

ROZENDAAL, D.M.A. et al. 2019. Biodiversity recovery of Neotropical secondary forests. Sci. Adv.

RUDORFF, C.; OLIVA, P.; OMETTO, J. P. Water quality longitudinal profile of the Paraíba do Sul river, Brazil during an extreme drought event. Limnology and Oceanography, 2017.

SAAD, Sandra Isay; DA ROCHA, Humberto Ribeiro; DA SILVA, Jonathan Mota. The impact of roads and sediment basins on simulated river discharge and sediment flux in an experimental catchment designed to improve ecosystem services. Hydrology and Earth System Sciences. 2016.

SCHIERMEIER, Q. 2014. Water risk as world warms. Nature 50510-11.

SILVA, Fernando das Graças Braga da et al. Previsão da perda de solo na Fazenda Canchim-SP (EMBRAPA) utilizando geoprocessamento e o USLE 2D. Engenharia Sanitária e Ambiental, Rio de janeiro, v. 15, n. 2, p. 141-148, 2010

SILVA, R. M. et al. Integration of GIS and remote sensing for estimation of soil loss and prioritization of critical sub-catchments: a case study of Tapacurá catchment. Natural Hazards, v. 62, n. 3, p. 953-970, 2012.

SOARES-FILHO, B., PENNACHIN, C. \& CERQUEIRA, G. 2002. Dinamica - a stochastic cellular automata model designed to simulate the landscape dynamics in an Amazonian colonization frontier. Environ. Model. Softw. $154217-235$.

SOARES-FILHO, B., RAJÃO, R., MACEDO, M., CARNEIRO, A., COSTA, W., COE, M., RODRIGUES, H. \& ALENCAR, A. 2014. Cracking Brazil' s Forest Code. Science (80-. ). 344(April):363-364.

TAFFARELLO, D., SRINIVASAN, R., MOHOR, G.S., LUIS, J., GUIMARÃES, B., CALIJURI, C. \& MENDIONDO, E.M. 2018. Modeling freshwater quality scenarios with ecosystem-based adaptation in the headwaters of the Cantareira system, Brazil. Hydrol. Earth Syst. Sci. 224699-4723.

TILMAN, D., ISBELL, F. \& COWLES, J.M. 2014. Biodiversity and ecosystem functioning. Annu. Rev. Ecol. Evol. Syst. 45471-493.

TSCHERNING, K., HELMING, K., KRIPPNER, B., SIEBER, S., \& PALOMA, S.G.Y. 2012. Does research applying the DPSIR framework support decision making? Land Use Policy. 29 (1): 102-110.

TYMUS, J.R.C., LENTI, F.E.B., SILVA, A.P.M. da, BENINI, R. de M. \& ISERNHAGEN, I. 2018. Restauração da vegetação nativa no Brasil. 
Dib, V. et al.

VIEIRA, R.R.S., RIBEIRO, B.R., RESENDE, F.M., BRUM, F.T., MACHADO, N., SALES, L.P., MACEDO, L., SOARES-FILHO, B. \& LOYOLA, R. 2017. Compliance to Brazil's Forest Code will not protect biodiversity and ecosystem services. Divers. Distrib. 1-5.

WATER NATIONAL AGENCY 2019 Agência Nacional das Águas. Retrieved from https://www.ana.gov.br/sala-de-situacao/sistema-cantareira/sistemacantareira-saiba-mais (10/10/2019)

WISCHMEIER, W.H. \& SMITH, D.D. 1978. Predicting rainfall erosion losses. A guide to conservation planning. USDA Agriculture Handbook, Washington.

ZAIMES, G.N. \& SCHULTZ, R.C. 2015. Catena Riparian land-use impacts on bank erosion and deposition of an incised stream in north-central Iowa, USA. Catena 12561-73.
ZAIMES, G.N., SCHULTZ, R.C. \& ISENHART, T.M. 2008. Streambank soil and phosporous losses under different riparian land-uses in Iowa. J. Am. Water Resour. Assossiation 44(4):935-947.

ZHANG, X., LIU, X., ZHANG, M., DAHLGREN, R.A. \& EITZEL, M. 2010. A Review of Vegetated Buffers and a Meta-analysis of Their Mitigation Efficacy in Reducing Nonpoint Source Pollution. J. Environ. Qual. 3976-84.
Received: 20/11/2019

Revised: 05/02/2020

Accepted: 27/03/2020

Published online: 11/05/2020 